\title{
Sense and Incompossibility: Deleuze's The Fold and the Baroque Jane Austen
}

\author{
Celiese Lypka and David Sigler \\ University of Calgary
}

Abstract: This paper offers an analysis of Jane Austen's novel Sense and Sensibility (1811) as shaped by a reading of Gilles Deleuze's The Fold (1988 which extols baroque architecture, music, and mathematics. With reference to Deleuze, we seek to show how Austen's discourses of interior design become folded into the characters' personalities and, from there, into the plot of the novel. This baroque process of overflowing and folding compos an interesting exchange between Austen and Deleuze, one that generates a surprising commonality between their understandings of space, events, subjectivity, and narrative.

Jane Austen's Sense and Sensibility (1811) opens with a detailed discussion of the Dashwood residence at Norland Park, using the family's tenuous relationship to this estate to introduce the characters through systems of kinship and inheritance. As the Dashwoods are forced to move away from their family home, Sense and Sensibility sustains its interest in architecture and interior design to a surprising extent. Interior design, we argue, quiet shapes point of view in a novel famous for its experiments with narration. Beyond simply indicating levels of prestige within a world of landed gentry the novel begins to theorize subjectivity through interior design. In this paper, we seek to show how Austen's discourses of interior design become folded into the characters' personalities and, from there, into the plot. As these elements of the novel become co-implicated, Austen rethinks the ba elements of interpretation: it becomes difficult to make distinctions between the novel's settings and its characters, then point of view and its narration, then narration and the narrative, and then the actual storyworld and other incompossible storyworlds, as each structure successively collapses in a distinctly baroque manner. This, we suggest, brings Austen into surprising alliance with the twentieth-century philosopher Gilles Delet and particularly his work in The Fold (1988), which engages with Leibniz, early eighteenth-century calculus, and the baroque to present subjectivity : a shifting set of points of view, created in and by their relation to infinity. ${ }^{[1]}$ The plot of the novel, with its inescapable conjugality derived from the women's tendency to confuse the Ferrars brothers, finds its resolution only as the novel learns to fold interior space, and thereby the structure of human subjectivity, and thereby the meaning of "events," and thereby narrative. The delicate interfolding of character, narrative, and setting proves unifying, even if these elements remain separately identifiable. Indeed, the strangely coherent accordance between seemingly dissonant elements within the novel invites a baroque reading, where foldings between divided structures generate unpredicted connections for a creative future. This unifying (if discordant) effect, we suggest, reveals not only a baroque Austen, but also a Deleuzian impulse for complicating structures of relations while composing infinite multiplicities.

Sense and Sensibility is concerned with the efficient and even over-efficient use of indoor space, to the point where its spaces achieve the impossib Even Norland Park, the novel's nostalgic symbol for the fading dignity of the landed gentry, is found to be "beyond calculation." ${ }^{[2]}$ It is a novel in whi Elinor Dashwood discovers, somewhat defensively, that in Robert Ferrars's hands even the closed quarters of a cottage can be, somehow, expansii - well beyond the constraints of common sense. If Elinor's accommodations at Dawlish are small, Robert explains, she has only herself to blame:

\begin{abstract}
Some people imagine that there can be no accommodations, no space in a cottage; but this is all a mistake. I was last month at my friend Elliott's, near Dartford. Lady Elliott wished to give a dance. 'But how can it be done?' said she; 'my dear Ferrars, do tell me how it is to be managed. There is not a room in this cottage that will hold ten couple, and where can the supper be?' I immediately saw that there could be no difficulty in it, so I said, 'My dear Lady Elliott, do not be uneasy. The dining parlour will admit eighteen couples with ease; card-tables may be placed in the drawing-room; the library may be open for tea and other refreshments; and let the supper be set out in the saloon.' . . . We measured the dining-room, and found it would hold exactly eighteen couple, and the affair was arranged precisely after my plan. So that, in fact, you see, if people do but know how to set about it, every comfort may be as well enjoyed in a cottage as in the most spacious dwelling. (189)
\end{abstract}

This is a very strange passage. Robert posits that the interior of a cottage can be vastly expanded without altering the structure-and so to think of small cottage as small is "a mistake." This undoes the ideological work from the opening of the novel, according to which landed estates confer soc prestige and cottages, humiliation. To the contrary, cottages may contain infinities.

Because Robert mansplains about cottages at such length, the novel presents the above passage as a ridiculous statement, evidence of his cluelessness and arrogance. But we still confront two parallax structures here, one embedded inside the other. In the outer section, we have Elinor begrudgingly listening to Robert's commentary, which in her point of view becomes a sign of his dullness but in his, it's a sign of hers. Yet his perspective contains a report of another parallax gap, such that in one perspective (Lady Elliott's) the interior space is very small and couldn't accommodate twenty people; in the other (Robert's), thirty-six people can be accommodated "with ease"-indeed, "there could be no difficulty in it and they might even be able to dance. This is a significant difference in scale, occurring twice over, and is indicative of more than their relative degre of comfort in densely populated rooms. As we can see, the question of point of view is already caught up, in multiple and enfolded ways, in the question of interior space. ${ }^{[3]}$ The narrator asks us to take Elinor's side in the matter as a means, it seems, of traversing these gaps; yet Robert's perspective, itself constituted by the gap between two incommensurate perspectives, remains irreducible here and quite astonishing in its claims. $P$ in Deleuzian terms, for Robert, a small cottage can be "a unity that envelops a multiplicity," which, in its "power of envelopment and development," delivers the inhabitants into "a universal Unity that "complicates' them all, and that complicates all the Ones." Such a cottage can function as "a large zone of 
immanence" and as an envelope. ${ }^{[4]}$ And its function as a physical envelope creates an enveloping set of viewpoints. Even Robert's explanation functions this way: it what Deleuze calls "the enveloping envelope," the structure that makes calculus aspire to the infinite. ${ }^{[5]}$ For Robert, it's not only that small spaces can be used more efficiently; it's that this capacity in them is truly limitless, and so a cottage can be as accommodating as "the most spacious dwelling," whatever the square footage. Yet, paradoxically, its limitlessness is achieved through rigorous exactitude (e.g., "exactly eighteen couple ... arranged precisely"). We find ourselves in the realm o calculus: the precision of the calculations somehow makes possible an endlessly expansive room, even "the most spacious dwelling." Austen has arrived at the same conclusion as will Deleuze: structures generate points of view and thus enable the formation of a monad, ${ }^{[6]}$ a multiplicity, out of and through the collation of infinitic For Leibniz, a monad was the aggregate term from the parts of matter, infinitely divisible, that could be collected into one world. ${ }^{[7]}$ Deleuze, building on Leibniz's work, maintained that monads could, and do, fold into each other to create dissonant and incompossible harmonies. Our claim in this paper is that point of view in Sense and Sensibility is monadic, built around a baroque process of folding and enfolding — something that might seem obvious, given Austen's pioneering work in developing free indirect discourse, but that shapes foundational features of the novel like character and plot.

It seems that Robert Ferrars is an aficionado of baroque cottages. He can recognize and express the unifying arrangements possible in architecture particularly those that would appear to have clearly demarcated interior and exterior spaces. Deleuze valorizes just such a baroque house in The Fo, as he imagines a building that generates more and more interior space through its subdivisions and its billowing, endlessly folded and re-folded fabrics: "The baroque refers not to an essence but rather to an operative function, to a trait. It endlessly produces folds ... [and] unfurls all the way infinity." [8] Such houses have two floors, he says, allegorically corresponding to the state of the soul in Leibniz's philosophy: the lower floor of the metaphorical house has the five senses as its window openings, while the upper floor is a windowless private room covered in drapery (i.e., folds), " if it were a living dermis." [9] The second floor is virtual and "affirmed to be strictly metaphysical. The soul itself is what constitutes the other floor or $t$ inside up above, where there are no windows to allow entry of influence from without."[10] The indoor and outdoor spaces appear to be totally separated, visually and conceptually: we find "the extreme tension of an open façade and a hermetic inner volume, each being independent of the other" and existing in "an almost schizophrenic tension." ${ }^{[11]}$ However, between these floors is another fold, like a correspondence or affinity, which extends from one level to the other and paradoxically announces the equivalency between the two-as well as reveals the potential for something more. This, explains Deleuze, is the intriguing complication of the fold: "The problem is not how to finish a fold, but how to continue it, to have it go through the ceiling, how to bring it to infinity." ${ }^{[12]}$ Such is exactly the sort of impossible space that Robert can engineer, upon finding a relation between the first and the second floor that leads to infinity: "For my own part,' said he, 'I am excessively fond of a cottage; there is always so mucr comfort, so much elegance about them'" (188).

At first glance, it might seem strange to focus on Robert's proud fascination with baroque spaces, as the novel goes out of its way to dismiss him as silly man with silly tastes. But Robert Ferrars is not so easily dismissed. D.A. Miller has taught us to see him-i.e., Mr. Robert Ferrars of the customordered toothpick case and the irritating lack of interest in women-as the engine of "unheterosexual" possibilities in this novel. ${ }^{[13]}$ Even at the level plot rather than style, he is a figure of pivotal importance, functioning as deus ex machina by marrying Lucy Steele and thus solving an otherwise unmanageable conjugal puzzle: "And by what attraction Robert could be drawn on to marry a girl ... was completely a puzzle," muses an appreciative if bewildered Elinor (276). He locks everything into place, even as he opens up unimagined possibilities for architecture and the plot-a this, only after the novel has introjected his peculiar manner. Although Austen seems to mock Robert through Elinor's perceptions for his ostentatiol taste, his excesses eventually become the novel's excesses, until Robert begins to function as the novel's spare replacement part (e.g., "Mr. Ferrars married"; "I meant . . . to enquire after Mrs. Edward Ferrars"; "Perhaps you mean-my brother-you mean Mrs. -Mrs. Robert Ferrars!" [268, 272]). Robert, who can read the folds in architectural spaces, also displays the folds inherent in apparent subjectivities. Thus, a novel which begins in cryptography - what Lucy Steele calls the "great secret" of "the letter F" (95) - ends by following the proliferation of the fold through its enveloping structures and into infinity.

Austen might seem like the least baroque of novelists, celebrated for her incisive wit, restrained moral values, syntactic precision, and backbiting iro She is relentlessly modern and modernist. Yet Austen is, as scholars have begun to notice, also steeped in the baroque. Michael Chwe highlights Austen's baroque structures of logic-structures that, he says, are both mathematical and musical. He emphasizes how Mary in Pride and Prejudice "deep in the study of thorough bass," the Regency term for the baroque. ${ }^{[14]}$ He quotes Denis Stevens, who explains that: "the seventeenth century, and the greater part of the eighteenth, were known to the majority of historians and critics as the period of the thorough-bass, and it is only in recen years that the term 'baroque' came to be accepted."[15] Austen, Chwe argues, teaches us "to approach human nature in the same way as thorough bass," that is, mathematically. ${ }^{[16]}$ Further, Janine Barchas shows how Northanger Abbey's references to the painter George Morland suggest an engagement with "Radcliffe's baroque Gothicism." [17] C. C. Barfoot maintains that Austen's fiction can be read "as an attempt, unsystematic but buoyantly creative," to approach questions strongly associated, at the time, with Leibniz's thought. Barfoot maintains, to our horror, that Leibniz's philosophy would have been "highly relevant" to "Austen's first novel," "had she cared to look," but that Austen shared a "feminine intelligence" witr George Eliot, preventing her from examining philosophical questions directly. ${ }^{[18]}$ Austen, then, for some time has been known to display a guarded $k$ thoroughgoing engagement with the baroque. Yet if scholars have sometimes read Austen's investigations of "thorough bass" and "human nature" c a comic "juxtaposition of the heterogeneous," [19] our analysis suggests the opposite-that "human nature" depends, at least in Sense and Sensibilit on the subject's radical incorporation of baroque processes and structures.

For Leibniz, the existing world is but one of an infinite number of hypothetical worlds, "incompossible" with each other and without hope of their intersecting. Each of these worlds is replete with infinite things, but all of those things have to be "compossible" with the others existing in that worl And yet, because God chooses the best possible world, constituted by "the totality of monads that convey the same world," the existing world is th only one that might have existed. ${ }^{[20]}$ The incompossible is never real or actualized, since "possible worlds cannot pass into existence if they are incompossible with what God chooses."[21] Even still, such a supposition offers a strategy for embracing contradiction. Deleuze identifies the potent crossing of the compossible and incompossible, embracing the infinite multiplicity of concurrent possible worlds; he sees a connection between the world that is actualized (the pleats of matter) and multiple virtual incompossible worlds yet unrealized (the folds of the soul) - another baroque 
structure unfolds. The incompossible, persisting as the underside of the world expressed by monads, reveals a small part of an alternate possible world. In effect, Deleuze curves Leibniz by reading incompossibility as a condition of compossibility: the world brims with events and subjects that $\varepsilon$ endlessly foldable, until the compossible and incompossible must co-exist. Hence Laci Mattison observes that, for Deleuze, "incompossibility is the fabric which contains everything," as, in its resemblance to the virtual, incompossibility finds not chaos or negation but possibility. [22]

To appreciate how Sense and Sensibility's plot exploits the incompossible, we first have to note how the spaces it imagines become folded into the characters, so that the characters begin to exist architecturally and dynamically. The Dashwood sisters make contact with the incompossible as the explore and decipher their own conjugal "possibilities," especially as they interact, and fail to interact, with Willoughby. The premises associated wit Robert Ferrars - that is, the commercial and residential spaces he seeks to control-become the premises of the novel's courtships and thus the resolution of its plot. The Dashwood sisters first meet Robert in such a space-at Gray's, the jeweler's on Sackville Street in London, whose second floor is strangely overfull: "On ascending the stairs, the Miss Dashwoods found so many people before them in the room, that there was not a perso at liberty to tend to their orders" (165). Like Lady Elliott's cottage, it is a room jam-packed with people and objects to an unlikely extent. Robert is, tc the Dashwoods' frustration, quite at ease there, ordering his custom toothpick case: "one gentleman only was standing there" (165). No mention is made of any windows or natural light. It occupies the second floor, as Deleuze would have hoped.

Sense and Sensibility has several such spaces, larger on the inside than on the outside, which are subject to measurement but, through being measured, manage to resist calculation. Barton Cottage, for instance, manages to be "comfortable" despite being "compact" and "defective" "as a cottage"; it is at one and the same time "too small for our family" and "tolerably comfortable" (22). As the novel concludes, Mrs. Jennings is overfillir Edward's cottage with furniture and workers. These spaces profoundly control the development of character in this novel: on the one hand fracturin! "point of view" until free indirect discourse is possible, and on the other hand subsuming peculiarities such as Robert's into larger unified structures, many of them hegemonic, enabling Robert Ferrars to function as a man within the novel's ideological scheme of enforced conjugality. After all, as Jc Dashwood quite rightly if cynically observes, "it must be the same to Miss Morton whether she marry Edward or Robert" (224). Their interchangeabi should not suggest that the differences between Edward and Robert, so clearly cultivated in their private and public educations, disappear. Rather, 1 baroque produces "unity in variety": "we go, not from monads to harmony, but from harmony to monads."[23] The Ferrars brothers, with Robert's lov of the baroque, become such a monad.

The novel also confronts the reverse problem: buildings that are actually spacious but seem, strangely, too small in subjective terms. As Mrs. Jennin notes: "but to hear a man apologising, as I thought, for a house that to my knowledge has five sitting rooms on the ground-floor, and I think the housekeeper told me could make up fifteen beds! . . It seems quite ridiculous" (220). She emphatically aligns these strangely mis-sized spaces witl the development of point of view and subjectivity - as if space cannot be measured by its square footage but only by the impression it gives.

But how can a folded space affect the Dashwoods so, when they are so skeptical of it; and how can the infiniteness of such a world shape domestic fiction? It is Austen's constrained scale that makes her fiction an endless space, a meta-textual version of Lady Elliott's cottage or a bejeweled toothpick-case: "it conveys the entire world, but does not express it without expressing more clearly a small region of the world, a 'subdivision,' a borough of the city, a finite sequence." [24] The objects assembled in Sense and Sensibility -the upstairs space at Gray's, Robert's toothpick-case, tr pianoforte at the party, and finally conjugality itself, which is, it appears for necessary economic reasons, "the object" of the Dashwood sisters' existence-become what Deleuze would call "objectile," or constantly in flux. In an objectile environment one begins to understand that innumerabl perspectives exist; one needs, in order to stave off chaos, to organize them into a number of delimited, dynamic points of view. ${ }^{25]}$ As the object transforms, per the "vectors of curvature" made possible in such a space, the subject comes to assume that point of view and thus transforms: "jus as the object becomes objectile, the subject becomes a superject."[26] Subjectivity is thus re-formed, Deleuze promises, through the folds of the baroque: "the subject will be what comes to the point of view, or rather what remains in the point of view."[27] Subjects aren't cordoned off from eacl other but are exposed to constant shifts between them, and "thus for the moment we only have a nominal definition of the individual."[28]

This sort of contingency, its provisional nature and flitting movements, becomes the hallmark of Austen's writing. As a concept, some worry the objectile has suffered from "overuse" in design circles as it became "lodged in the stratum of the architectural" by designers rather than finding new philosophical contexts. ${ }^{[29]}$ Yet, Austen renders that a false choice, using her architectural thinking to challenge or remake ontology. She causes subjects-especially the Dashwoods themselves - to become superject. Free indirect style rethinks the subject in a specifically baroque way, neithe insisting on the primacy of any one perspective nor collapsing the difference between perspectives. It relies upon counterpoint; its movement is vectorial, projective, endlessly enfolding, and infinitely variable. Austen presents "point of view as the secret of things, as focus, cryptography, or evi as the determination of the indeterminate by means of ambiguous signs," because "as in a Baroque anamorphosis, only point of view provides us $\mathrm{n}$ answers and cases."[30] Transformations of character then shape plot, as shifting perspectives enable the reader, and the Dashwoods, to decode th novel's cryptographic "F."s; identify its suddenly interchangeable Ferrarses; perceive the personalities of John Willoughby, Colonel Brandon, and Lur Steele; and also to grasp secret conjugal engagements and keep them secret. Decryption becomes the novel's pathway to its unsatisfying conclusic which re-shuffles the conjugal arrangements and cordons certain couples into separate worlds instead of punishing or rewarding anyone.

As such, Sense and Sensibility doesn't have a plot so much as a series of events that have to be decoded and rearranged. And the decodingrearranging is possible only when point of view becomes destabilized, at least provisionally, through acts of sympathy and narration. We maintain th the novel's approach to "event" is an outgrowth of its experiments in point of view, which are themselves outgrowths of Austen's willingness to enfo space in a baroque way. The plot, too, becomes folded in the process, as it comes to depend on Robert Ferrars's baroque capaciousness to manac its marriage plot. Peter J. Rabinowitz has cautioned that the overemphasis on "event" within narrative theory diminishes our ability to perceive the characters' subjective experiences of the story. ${ }^{[31]}$ Deleuze's theory of "event" seems poised to solve that problem, and enables us to reimagine the processes of narrative in a way that makes the plot of Sense and Sensibility more satisfying. An event, for Deleuze, marks "the becoming of becomings, or . . . disjunctive eternity," as Alain Badiou explains, even while it "intensifies bodies, [and] concentrates their constitutive multiplicity."[ The Deleuzian event relies upon affect to collapse any distinction between oneself and the outer world, exposing selfhood to a dynamic, unending 
process of immanence: indeed, "unlimited becoming becomes the event itself."[33] Deleuze elaborates on these ideas in The Fold, finding that Leibniz's monads become events when they fill with "prehensions," which, by exceeding subjective space while remaining anchored in the body an in affect, create harmonies through "an emancipation of dissonance" among otherwise incompossible worlds. ${ }^{\text {[34] }}$

Consider, for example, how Marianne and Willoughby's courtship proceeds through folds and envelopes, exactly the mechanisms that sustain Robert's interest in interior design. Willoughby signals his supposed interest in Marianne by enveloping a lock of her hair in paper, then folding the paper, and then enveloping the fold within more paper: "he kissed it, and folded it up in a piece of white paper; and put it into his pocket-book" (46). We are meant to believe, as are the Dashwoods, that this act of folding communicates and extends Willoughby's feelings for Marianne within the limitless spaces of the envelope. Later Marianne also attempts to communicate with Willoughby through the folding systems of the post: "in length i could be no more than a note; it was then folded up, sealed, and directed with eager rapidity" (120). These are, to adapt from Anneke Smelik's readi of Deleuze, "folds that take on a life of their own," creating metonymic signifiers (hair, pocket-book, letters that receive no reply) that overwrite or replace the courtship itself. ${ }^{[35]}$ This is, of course, the mere illusion of courtship, but the illusion generates a realization of the possible extension of character towards a new unity. As Deleuze says: "the essence of the Baroque entails neither falling into nor emerging from illusion but rather realizin! something in illusion itself, or of tying it to a spiritual presence that endows its spaces and fragments with a collective unity."[36] Here we see how Austen plays with the concept of folding, with both objects and characters (and thus plot), in a way that bears a striking accord with Deleuze: throuc the composition of folds that complicate and extend the individual. For Deleuze, folds are processes that not only destabilize the certainty of events and subjectivity, but also reveal how movements toward infinity may lead to a creative new future: one that Austen explores in the contingency of h€ characters and plot. As in the folded architectural spaces of the novel, Marianne and Willoughby converge to trouble the dichotomies of exterior anc interior, appearance and essence, and surface and depth; they dispel illusions of separation in a baroque fashion. In so doing, they generate possibilities. Proceeding by a process of extension "that distends the world," per Deleuze, ${ }^{[37]}$ the possibilities converge in the fold between the seemingly conflicting levels of the baroque.

Thus, the novel continues to present Marianne's abandonment by Willoughby as a matter of "unfolding," which is not the opposite of folding but par of its elaboration. Elinor says, exasperatedly: "Yes, we do know it all. This seems to have been a day of general elucidation, for this very morning firs unfolded it to us" (148). It is important not to see this disappointment as the reversal of the earlier courtship, but only as a new stage in the Dashwoods' learning to inhabit the illusion of endlessness created by the fold. They are "discovering new ways of folding, akin to new envelopment: but . . . what always matters is folding, unfolding, refolding."[38] The folding and enveloping that transpires between Marianne and Willoughby, as it becomes the very substance of their courtship, ensures that the novel escapes the oppositions it had threatened to construct, between Willoughby': presence and absence, Marianne's excitement and disappointment, her health and illness, and hiddenness and openness. As Smelik explains, the $f$ "opens the subject up to a process of infinite becoming," being, as it is, "an interface . . . and as such demolishes binary oppositions."[39] Read in such terms, Willoughby's secret enfolding of Marianne's hair into his pocketbook mirrors the baroque structure of the cottage at which it transpires, and implies the folding of the world into the self. To resolve the mystery of Willoughby-and by extension that of Brandon and the brothers Ferrars, and the mysteries of conjugality per se-"a 'cryptographer' is needed, someone who can at once account for nature and decipher the soul, who car peer into the crannies of matter and read into the folds of the soul." [40] Existing Austen scholarship presents Marianne's eventual union with Brando as one of "compromised disposition" [41] determined by "outrageous acts of chance" and "a refusal of social integration." trying multiple combinations until we can determine which Ferrars is which, which suitor is reliable, who should benefit from Brandon's generosity, a what constitutes a meaningful event. The reader is called upon to provide these acts of cryptography, a task they are trained into alongside the Dashwoods. These determinations, though, are for the Dashwood sisters acts of introspection.

An internal realization moves Marianne through the event of courtship, an inflection that redirects her movements and makes possible her attraction Brandon by allowing a more comprehensive vision of her self to unfold. It is a self in which body and soul endeavor to harmonize, like the fold betw€ the levels of the baroque house, and which reorients Marianne's relationship to events as such. Austen's narrative experiments with events that mov "from fold to fold and not from point to point," as Deleuze puts it. [43] Rather than expressing events as structured points that move in linear succession, the Dashwoods navigate a series of foldings and unfoldings that actualize possibility. Events in this way of reading are neither disruptior nor the fulfillment of the plot, but rather creative movements that unearth the immanent potentiality that exits underneath the narrative structure. Thi: is what makes Sense and Sensibility so radical and, in a conventional sense, so unsatisfying; as Thomas Keymer observes, it "refuses to conform to the lineaments of the sentimental novel" and doesn't really disabuse Marianne of her sensibility, given that her concerns are actually "more or less right." [44] To interpret such a plot or take it seriously requires us to reimagine Marianne's "false step[s]" (32), as the novel calls them, as the folding al unfolding attendant to self-transformation. Such is how Sense and Sensibility thinks about events - as the pursuit of an internal path constantly enfolding the outside world within its compass, rather than as a set of random or fated occurrences that befall someone.

Events ramify here at the level of character, ensuring that body and soul continue "happening" as "a pure vitality and possibility ... [,] the pure predicate." [45] To think about an event in this way is to rethink the meaning of meaning itself, so that a plot can proceed through, rather than cause, internal transformation that, in its procedures, actually dismembers the division between internal and external, character and setting. Note how Austen's strangely sadistic narrator becomes interested in: "the difference between the expectation of an unpleasant event, however certain the min may be told to consider it, and certainty itself" (270). This minimal difference, opening up at the level of individual psychology (e.g., "the mind") and $\mathrm{i}$ operations (e.g., "certainty," "expectation"), makes plot points matters of thought rather than external occurrences. As Deleuze elaborates in The Lo of Sense, "The Event is not what occurs (an accident), it is rather inside what occurs, the purely expressed. It signals and awaits us."[46] To explore how this mode of baroque subjectivity remakes seeming accidents as matters of the soul, we shall momentarily consider Marianne's sprained ankle the most fateful "accident" of Sense and Sensibility, by tracing its impact on Marianne's internal life and on Willoughby's changing place inside and outside the narrative. A Deleuzian mode of thinking about event confounds the gap between interior and exterior space to produce a monad, a baroque unfolding that renders Willoughby not just undesirable but actually incompossible. 
Willoughby finds his way into the novel through immersion in its baroque spaces, rendering himself available as an object for courtship within the possible world of the novel's marriage plot only to be expelled into a parallel, separate, and incompossible existence. Marianne first meets Willoughl in chapter 9 when she sprains her ankle. The event is an effect of the psychology made possible by architecture: "the girls had ... discovered an ancient respectable looking mansion, which, by reminding them a little of Norland, interested their imagination and made them wish to be better acquainted with it" (31). Thus Marianne's desire for Willoughby, as made possible by her "false step" which "brought her suddenly to the ground" ( 3 : is said to be an outgrowth of her desire for baroque space (e.g., "made them wish"). The Dashwoods' desire for the inside of the mansion becomes, by extension, Marianne's desire for Willoughby's "exterior attractions" (33), a toggling between inside and outside as mediated by an event registere on and in her body, parts of which were "twisted in her fall" (32). Their attraction soon affirms the fold, and seeks to hide in folds: their time together, being "exactly calculated to give increasing intimacy" (41), leads to a continuous process of folding, refolding, and unfolding affections. The novel gives us numerous signals of Willoughby's poor moral character-from his attempts to calculate Marianne's needs exactly, his cheating at cards to Marianne's advantage, and the aforementioned "false step"-but it also emphasizes the ways that these red flags, so readily apparent to Elinor, find their correspondence in Marianne's subjective experience: "their behaviour, at all times, was an illustration of their opinions" (41). It is, as the novel notes, "a strange kind of tenderness" (61).

Thus, Willoughby's courtship becomes a dangerous folding of possibility and incompossibility, one that, to a curious extent, depends upon question of interior design. Willoughby initially appears to be someone for whom courtship would be "more strange and more incompatible" (54)-he is the vt figure of incompossibility. A beacon of heterogeneity, he appears to be the keeper of a blank secret, a "strange kind of secrecy ... [which] in fact contained nothing at all" (54). Yet, the Dashwoods begin to enfold him into their domestic space, a process that activates him, temporarily, as a viab part of the marriage plot. Willoughby loves Barton Cottage and demands it not be changed, and even fantasizes about building a replica at Combe: "The cottage seemed to be considered and loved by him as his home; many more of his hours were spent there than at Allenham" (55). Willoughby": immersion in the cottage space shapes him affectively, enabling him to emerge as compossible to the Dashwoods' world: "His heart seemed more than usually open to every feeling of attachment to the objects around him," and so he "opposed every alteration of ... [the] place" (55). Like Rober Ferrars, Willoughby feels at ease in cramped quarters, but unlike Robert he is obsessed with its remaining unaltered, a notion that ultimately indicate his unsuitability for Marianne. Indeed, he strenuously objects to any renovation: "Not a stone must be added to its walls, not an inch to its size, if my feelings are regarded," he says, as "I consider it as the only form of building in which happiness is attainable" (55). There is a temptation to read his attachment to Barton metonymically, as a signal of his affection for the Dashwoods as they are-even though he admits that he had already covetec the cottage when it was uninhabited. Yet his comments veer from the affectionate to the obsessional, suggesting Willoughby's terror at objectile spe and its potentialities: "Tell me not only that your house will remain the same, but that I shall ever find you and yours as unchanged as your dwelling,' he demands of Mrs. Dashwood (56).

Yet, when Willoughby breaks off with Marianne by not replying to her letters, he becomes not just disappointing or villainous but incompossible. He ceases to have a possible part in the Dashwoods' world: "It is too much! Oh! Willoughby, Willoughby, could this be yours! Cruel, cruel-nothing can acquit you," Marianne says (142). It is not that Willoughby has become a poor option for Marianne, but that he has become someone who inhabits another world entirely, as suggested by his unresponsiveness. As the Dashwoods learn about him, from their own experiences and from Brandon's shocking report, Willoughby becomes utterly outcast: "It would be unnecessary I am sure, for you to caution Mrs. Palmer and Sir John against ever naming Mr. Willoughby" they say, as "the less that is said about such things, the better;" effectively, he is "blown over and forgot" (146). When Willoughby returns near the end of the novel, drunkenly, out of self-serving guilt and concern for Marianne's health, Elinor patiently explains, to his bewilderment, that he cannot be re-incorporated into their narrative. He thus appears as an alien intruder: Elinor expresses "amazement" that he would want to interact "with me!," experiencing the intrusion as "violent" (240). The narrator closes him out of the scene, forcing us instead to look $\varepsilon$ Elinor looking at him, "starting back with a look of horror at the sight of him" (239). The interaction, it would seem, cannot form part of the narrative: "Such a beginning cannot be followed by anything," Elinor worries (242).

Willoughby, it is true, confesses his motives - a "dread of poverty" (245) -in marrying Sophia, in a misguided attempt to curry the Dashwoods' sympathy. But Elinor is more confused than afraid or concerned, calling his words "beyond my comprehension" (244), explaining to him that he sim/ cannot be re-enfolded into the Dashwoods' world, even to apologize or explain. He now exists in another world entirely, without any intersection wit the Dashwoods'. As the novel ends, Willoughby isn't regretful or sad, but merely living on some other plane of existence: "But that he was forever inconsolable, that he fled from society, or contracted an habitual gloom of temper, or died of a broken heart, must not be depended on-for he did neither. He lived to exert, and frequently to enjoy himself . . . he found no inconsiderable degree of domestic felicity" (288-89). As the marriage plot snaps into place around Marianne and Brandon, Elinor and Edward, and Lucy and Robert, Willoughby is jettisoned into an alternate universe to "enj himself."

Austen marks Willoughby's incompossibility, and other similar events, as happenings that change the characters' perspectives, as well as the form c the plot. The movements of the novel are those of infinite virtual possibilities, which are made real through baroque expression-yet another surprisi alliance between dissimilar structures and events. Thus, we can read the events that the Dashwoods pass through as revealing the unifying divergences and variations in the folds of the fictional world. At first blush, the novel appears to suggest that a young woman can align herself with either "sense" or "sensibility," and that the two elder Miss Dashwoods have each chosen one perspective and thus are "so exactly the reverse of" o another (79). Indeed, the sisters hold opposing viewpoints on most matters. The Dashwoods simply tend to disagree about what is possible. When Colonel Brandon inquires of Elinor as to whether or not her sister believes in the possibility of falling in love more than once, he receives the followin answer:

'No,' replied Elinor, 'her opinions are all romantic.' / 'Or rather, as I believe, she considers them impossible to exist.' / 'I believe she does. But how she contrives it without reflecting on the character of her own father, who had himself two wives, I know not. A few years however will settle her opinions on the reasonable basis of common sense and observation.' (43) 
Austen clearly marks the difference in the sisters' positions. Marianne finds second attachments in love to be impossible, while Elinor believes that Marianne is misguided by youthful sensibility that over time will give way to a more sensible understanding of love. As readers, we are encouraged $t$ see that Elinor is, in some ways, correct. Marianne does shift her viewpoint at the end of the novel when she replaces her affections for Willoughby with her feelings for Brandon.

Although the shift indicates Marianne's maturing from sensibility to sense, as Elinor hoped she might, it also can be thought to reflect an "indefinite article" of possibility, which emerges from the "chaotic multiplicity" of the virtual world. ${ }^{[4]}$ Marianne, as Elinor describes her, is an assemblage of "incontinent feelings," and "her systems have all the unfortunate tendency of setting propriety at nought" (43). The shift in "her systems" is a creativ movement that suggests, as does Deleuze, that the body becomes actualized through the expression of an event. It is not that Marianne has learne to regret her previous sensibilities through the experience of Willoughby's deceit, but that Willoughby's betrayal (qua event) unlocks the possibilities that underpin her character and allow her to express a new fold-a virtual self that was always there. Marianne's journey of self-discovery requires $\mathrm{h}$ to fold and unfold within the binary structures afforded by her romantic couplings:

Marianne Dashwood was born to an extraordinary fate. She was born to discover the falsehood of her own opinions, and to counteract, by her conduct, her most favourite maxims. She was born to overcome an affection formed so late in life as at seventeen, and ... voluntarily to give her hand to another! (288)

The narrator brazenly describes Marianne's unfolding as a progressive movement that "overcomes" her closed self. Her emergence actualizes the virtual, aligning with Deleuze's assertion that "the predicate is an event, and appears in the subject as a change in perception." "[48] It is a change not character but in perception, an inflective movement for Marianne and the reader between the two floors of the baroque house. Even as the characte "retain an irreducible individuality," they fold into each other provisionally and spontaneously, moving "from fold to fold."[49]

As the plot progresses, both Elinor and Marianne take up positions that they had previously negated or thought impossible: Elinor marries Edward, and Marianne finds herself in a second attachment with Brandon. Like the machinic complicity between Elinor and Marianne's divergent personaliti there is also a correlation between the folding aspects of their individual selves; they are disrupted from their stability set in the matter of social expectations from the enfolding of their virtual desire and thus obtain what they had previously deemed impossible. In this way, there is an affiliation between the two conditions of the Dashwoods: a unification of the baroque house. Deleuze explains this as "a correspondence and even a communication between the two levels . . . between the pleats of matter and the folds in the soul. A fold between the two folds?"[50] Elinor and Marianne both communicate through their folding selves: not only to other characters who behold their shifting perspectives, but also to their own selves - after all, to fold or unfold is "to convey what one contains." ${ }^{\text {[51] }}$ Furthermore, through folding, this reading essentially counters the careful structuring of the text's binary pairings; it shows that Austen does not compose the world as intrinsically divided but rather endlessly moving towarc the various possibilities contained within the world. For Austen, as for Deleuze, folding is a becoming, the actualization of an incompossible world.

As Margaret Anne Doody notes in her introduction to the novel, we might think of Sense and Sensibility as having a "folding structure, whereby the novel is divided into two-like a hinged toothpick-case" or "scissars" and "tells two stories, which work against and with each other. Yet we have to go through one to get to the other" (xxxv-i). Claudia Johnson, meanwhile, marvels at the "insistent redundancy" of the plot, its use of "two Elizas," $a$ the "two unfortunate heroines," when "one would have sufficed." [52] The doubling is a profoundly Deleuzian structure, such that: "the world is actualized in souls, and is realized in bodies. It is therefore folded over twice."[53] Doody reads the double-folded structure in the novel's two plotline the first showcasing the "proprieties and acceptances" of civil society (xxxvi), and the second dealing with "the possibilities of what is usually subjugated, glossed over, or ignored in polite society" (xxxvii). However, as Doody notes, Austen does not divide these worlds, rather she illustrates their inherent connection and reveals an investment in the twofold world. In Sense and Sensibility there are doubled siblings (Mr. Dashwood and Marianne/Elinor, Fanny and Edward/Robert, Marianne and Eliza Sr./Eliza Jr.) and doubled couplings (Edward and Lucy/Elinor, Lucy and Edward/Robert, Marianne and Willoughby/Brandon, Willoughby and Marianne/Ms. Grey), but the pairings are not as clearly divided along the lines 0 "sense" or "sensibility" (internal or external) as an initial reading might suggest. This is because further to these doubled pairings is another folding that runs through the novel, the folding of characters themselves, not as a practice of doubling, but of becoming through creative actualization of an alternate possibility - a folding together of the pleats of matter and the folds of the soul.

The baroque house, says Deleuze, metaphorizes the folded subject, illustrating the gap between matter and monad. Elinor and Marianne reveal the nature of the fold as a multiplicity of possibility between the two coordinates. The novel aligns Elinor with a realistic "sense" and Marianne with the conjecture of "sensibility," placing both characters in a state of divided but relative stability. However, where Elinor reads Marianne's disposition as a "system" of sensibility differing from her own rationality, she fails to regard her own rationality similarly, as a mode of social production. Elinor thus effectively ensures that "the body works like a machine" to produce a state of stability fueled by organized desire, replicating the functions of the firs floor of the baroque house. ${ }^{[54]}$ Ironically, it is Marianne who observes the common production between their differing organized states:

'You have no confidence in me, Marianne.' / 'Nay, Elinor, this reproach from you-you who have confidence in no one!'/ 'Me!' returned Elinor in some confusion; 'indeed, Marianne, I have nothing to tell.' / 'Nor I,' answered Marianne with energy, 'our situations then are alike. We have neither of us any thing to tell; you, because you do not communicate, and I, because I conceal nothing.' (126)

In this missed encounter between their differing perspectives, Marianne finds commonality between Elinor's supposed real-world applications and $h$ own imaginative sensibility. Yet, there is also a gap between the real and the virtual at work here. Put in Deleuzian terms, Elinor and Marianne are bo assemblages of organic matter that, through their differences, display their fictional world as it actually is. They anatomize the world of organized social "proprieties and acceptances" and so can reveal horrific economic and social mechanisms governing the Fanny and Robert Dashwoods of th 
world. This exposition raises the possibility of another curved self - a form of subjectivity removed from society and containing a whole world within Like the fold that unifies the first and second floor of the baroque house, Elinor and Marianne's curved selves might envelop their mechanized characters: i.e., sense and sensibility.

Hence the Dashwoods envelop their material selves with new visions of what is possible, and extension of their folded selves towards infinity, as expressed in the novel's ending. Austen's epilogue assesses each character against the conventional happy ending of marriage plots. However muc the novel invests in the feminine gender position, and commits to distinctions of class and social order, as well as issues of law and property syster still arches toward infinity with a curved marriage plot that tarries with incompossibility. Austen playfully constructs a world in which the preestablished security of well-matched couples is displaced by a correlation of creative events that unfold to an unknown future. This is not to say tha' the novel revels in chaotic uncertainty - certainly, the novel closes with a sense of comfortable, if unsatisfying, resolution in the couplings and harmc of the characters-but still there is a discord that underpins the narrative. It is the disjunction between what the characters once deemed as $\mathrm{im}$ /possible and their final conjugal arrangements. Noting the ironic shifts in affections and couplings-Elinor marries Edward, Mrs. Ferrars approves Robert and Lucy, Marianne takes on a second attachment, and Willoughby finds "domestic felicity" with Sophia-the narrator concludes that despit the improbability of all of this, "nothing could exceed the harmony in which they all lived together" (287).

The harmonious picture at the end of the novel is not one in which a pre-established order of the world is revealed as the perfect compossible outcome, but rather it is a harmony that envelops the divergences, bifurcations, and incompossibilities within the same universe. It is a baroque cho that envelops the inherent compossibility of discord. As Mattison reminds us, "incompossibility is revealed as the originary state of existence: everything is part of the same fabric . . . Thus, binary opposition, such as harmony and dissonance, becomes irrelevant. It is, after all, through dissonance that supposed harmony is created."[55] The implicit contradictions of the text-how things once thought impossible are revealed as actualized events - are creative movements that "recognize and affirm textual and textural incompossibility, the everything-at-once, the unlimited bifurcations of the world."[56] While Marianne deftly illustrates the predicate as the virtual in the world, Elinor displays the bifurcations of the world as harmonizing infinite chord: "The past, the present, the future, Willoughby's visit, Marianne's safety, and her mother's expected arrival, threw her altogether into an agitation of spirits which kept off every indication of fatigue" (253). In this highly affective moment, Elinor experiences the polychronic time of multiplicities like a musical note that reinvigorates her sensibilities, opening up an interaction with possibility and becomings.

Elinor, like the novel's plot, experiences the movement of the fold and creates spontaneous "accords that are made and are undone," drawn togeth "from [her] own depths."[57] This creative movement of the fold is fully realized in the novel's ending, where Elinor's marriage to Edward constructs a chaotic harmony made through differential relations between the Dashwoods, Ferrarses, and Brandons. That Austen can think about the generative potential of multiplicities in this way, and from within the normative space of the marriage plot, reveals a radical tendency toward becoming in a novelist frequently held to be a "conservative icon." [58] Austen, in moments like these, reveals the harmonic chord of compossible and incompossib| worlds that somehow manage to reconcile and unify divergences. This baroque process of overflowing and folding composes an interesting exchan between Austen and Deleuze, one that generates a surprising commonality between their understandings of space, events, subjectivity, and narrati The commonality, based on a structure of interior design, reveals the possibilities of contingency that stretch out to infinity. Austen extends the nov $\epsilon$ baroque architecture into its formal (e.g., setting, event, plot, free indirect discourse, and point of view) and ideological (e.g., conjugality, sensibility, self-improvement, and morality) elements. Filling the subject with the world that supposedly contains it, Austen construes the subject of conjugality expansively to create a radical monadology.

\section{Notes}

1. Deleuze reflects on the exaggerated and elaborate motion and detail of baroque artistic style in order to theorize the function of the fold (his operative concept of the baroque) in which to destabilize the dichotomy of Cartesian subjectivity. His reading of the baroque through Leibniz works through the dualism of the subject (expressed in the allegory of the two story baroque house), creates a unification between disparate elements by reading baroque architecture's unique relationship between the exterior and interior, and considers the overflowing folding of material in baroque fashion to express the fold as a movement toward infinity.

2. Jane Austen, Sense and Sensibility, ed. James Kinsley (Oxford: Oxford University Press, 2008), 21. Further references to this edition given parenthetically.

3. We can see from the passage above how Robert identifies a Deleuzian understanding of space as outlined in "The Exhausted" from Essays Critical and Clinical: "Space has potentialities inasmuch as it makes the realization of events possible; it therefore precedes realization, and potentiality itself belongs to the possible" (160). Space for Deleuze, and it would appear for Austen, is not only a perspective of point of view I also an integral component to potentiality itself through the intensive qualities of spatial design.

4. Gilles Deleuze, The Fold: Leibniz and the Baroque, trans. Tom Conley (Minneapolis: University of Minnesota Press, 1993), 23-24.

5. Ibid., 22.

6. A monad, for Deleuze, refers to subjects or objects that express a singular perception of the world that is, in and of itself, variable. This variati is one in which the monad or subject apprehends the possibility of variation, rather than a contradictory state of affairs: "As an individual unit each monad includes the whole series; hence it conveys the entire world, but does not express it without expressing more clearly a small regi of the world, a 'subdivision,"' (The Fold 25).

7. Simon Duffy, Deleuze and the History of Mathematics: In Defense of the "New" (New York: Bloomsbury, 2013), 38-42.

8. Deleuze, The Fold, 3.

9. Ibid., 4.

10. Ibid., 13. 
11. Ibid., 32-33.

12. Ibid., 34 .

13. D. A. Miller, Jane Austen, or, The Secret of Style (Princeton: Princeton University Press, 2003), 16.

14. Michael Suk-Young Chwe, Jane Austen, Game Theorist (Princeton: Princeton University Press, 2014), 232.

15. Denis Stevens, "Introduction," in The Art of Accompaniment from a Thorough-Bass as Practiced in the XVIIth and XVIIIth Centuries, by F.T. Arnold (Mineola, NY: Dover, 1965), vii, qtd. in Chwe, 232.

16. Chwe, Jane Austen, Game Theorist, 232.

17. Janine Barchas, "Artistic Names in Austen's Fiction: Cameo Appearances by Prominent Painters," Persuasions: The Jane Austen Journal 31 (2009): 146.

18. C. C. Barfoot, The Thread of Connection: Aspects of Fate in the Novels of Jane Austen and Others (Amsterdam: Rodopi, 1982), 9, ix.

19. Robert K. Wallace, Jane Austen and Mozart: Classical Equilibrium in Fiction and Music (Athens: University of Georgia Press, 2009 ), 10.

20. Deleuze, The Fold, 63.

21. Ibid.

22. Laci Mattison, "Woolf's Un/Folding(s): The Artist and the Event of the Neo-Baroque," in Contradictory Woolf: Selected Papers, ed. Derek Ryar and Stella Bolaki (Clemson: Clemson University Digital Press, 2012), 98.

23. Deleuze, The Fold, 128-29.

24. Ibid., 25.

25. Gregg Lambert, The Non-Philosophy of Gilles Deleuze (New York: Continuum, 2002), 60.

26. Deleuze, The Fold, 20.

27. Ibid., 19.

28. Ibid., 25.

29. Derek Hales, "Re-Designing the Objectile," in Deleuze and Design, ed. Betti Marenko and Jamie Brassett, Deleuze Connections (Edinburgh: Edinburgh University Press, 2015), 146.

30. Deleuze, The Fold, 22.

31. Peter J. Rabinowitz, "They Shoot Tigers, Don't They?: Path and Counterpoint in The Long Goodbye," in A Companion to Narrative Theory, ed James Phelan and Peter J. Rabinowitz (Malden, MA: Wiley-Blackwell, 2008), 183-84.

32. Alain Badiou, "The Event in Deleuze," trans. Jon Roffe, Parrhesia: A Journal of Critical Philosophy 2 (2007): 38.

33. Ibid.

34. Deleuze, The Fold, 80-82.

35. Anneke Smelik, "Fashioning the Fold: Multiple Becomings," in This Deleuzian Century: Art, Activism, Life, ed. Rosi Braidotti and Rick Dolphijn (Amsterdam: Brill, 2014), 43

36. Deleuze, The Fold, 125.

37. Ibid.

38. Ibid., 137.

39. Smelik, "Fashioning the Fold," 38.

40. Deleuze, The Fold, 3.

41. William H. Galperin, The Historical Austen (Philadelphia: University of Pennsylvania Press, 2003), 120.

42. Claudia L. Johnson, Jane Austen: Women, Politics, and the Novel (Chicago: University of Chicago Press, 1988), 72

43. Deleuze, The Fold, 17.

44. Thomas Keymer, "Northanger Abbey and Sense and Sensibility," in The Cambridge Companion to Jane Austen, ed. Edward Copeland and Juliet McMaster, 2nd ed. (Cambridge: Cambridge University Press, 2011), 35-36.

45. Deleuze, The Fold, 105-6.

46. Gilles Deleuze, The Logic of Sense, ed. Constantin V. Boundas, trans. Mark Lester and Charles Stivale (New York: Columbia University Press, 1990), 149.

47. Deleuze, The Fold, 76 .

48. Ibid., 69 .

49. Ibid., 9.

50. Ibid., 4.

51. Ibid., 110

52. Johnson, Jane Austen, 57

53. Deleuze, The Fold, 120.

54. Ibid., 10.

55. Mattison, "Woolf's Un/Folding(S)," 96.

56. Ibid.

57. Deleuze, The Fold, 132.

58. Julian North, "Conservative Austen, Radical Austen: Sense and Sensibility from Text to Screen," in Adaptations: From Text to Screen, Screen 1 Text, ed. Deborah Cartmell and Imelda Whelehan (London: Routledge, 1999), 38.

\section{Cite this Essay}


https://doi.org/10.20415/rhiz/033.e03

RHIZOMES ISSN 1555-9998 $\star 230$ East Hall Bowling Green State University Bowling Green, OH 43403 Editors: Ellen Berry and Carol Siegel. Reviews editor: Craig J. Saper. Technical editor: Helen J Burgess 